\title{
CONSERVADORISMO, LIBERALISMO ECONÔMICO E O CASO BRASILEIRO
}

\author{
Hermógenes Saviani Filho
}

\begin{abstract}
Resumo: O artigo pretende apresentar como as ideias conservadoras têm obtido ressonância na sociedade brasileira, estimulada principalmente pelos meios de comunicação, e como isto têm influenciado a política, a economia e as relações sociais. Os grandes pensadores conservadores afirmam que o modelo não pode ser generalizado e que ele tem características próprias em cada sociedade. Entretanto, existem alguns princípios basilares que o orientam independentemente do local em questão. No Brasil, observamos que existe algo de peculiar, que ouso afirmar oportunista, em relação ao pensamento conservador. Por aqui, existe uma adaptação que insere não apenas os valores em questão, mas os misturam com os liberalismos político e econômico.
\end{abstract}

Palavras-chave: conservadorismo, liberalismo, política, moral.

\begin{abstract}
The article aims to present how the conservative ideas have resonance obtained in Brazilian society, mainly stimulated by the media, and how this has influenced the politics, economics and social relations. The great conservative thinkers claim that the model can not be generalized and that it has its own characteristics in each society. However, there are some basic principles that guide wherever issue. In Brazil, we see that there is something peculiar, which I dare to say opportunistic, compared to conservative thought. This way, there is an adaptation that enters not only the values in question, but mix them with political and economic liberalism.
\end{abstract}

Keywords: conservatism, liberalism, political, moral.

\section{Introdução}

Este artigo foi pensado como um texto acadêmico padrão, entretanto, com o decorrer das leituras feitas sobre os 'conservadores', e outras de apoio decidi escreve-lo da mesma forma em que eles - conservadores - o fazem. A explicação é simples, nos últimos anos vem se acentuando

\footnotetext{
.* Doutor e Mestre em Economia pela UFRGS e professor do Departamento de Economia pela mesma instituição.
} 
cada vez mais no Brasil este tipo de influência, que nas demais partes do mundo são consideradas minoritárias seja na academia seja na vida pública. O fenômeno que ocorre por estas bandas é a grande influência da mídia, da anemia e da falta de propostas da oposição a partir das sucessivas vitórias dos governos petistas. Isto, em termos internos, aliado aos sucessivos triunfos de partidos de esquerda na maior parte dos países sul-americanos, pelo lado externo, acendeu a luz amarela na elite brasileira e a vermelha a partir da vitória da Presidenta Dilma Rousseff em outubro de 2014.

Esses ‘conservadores’ passaram a ganhar espaço cada vez maior nas páginas e no tempo de rádio e televisão das principais mídias nacional para exporem suas 'ideias'. Muitos desconhecidos e outros nem tão desconhecidos, mas, provavelmente querendo sentir seu ego massageado, pressentiram, corretamente, que tinham ali um filão para aparecerem e terem seus ' 15 minutos de fama' da celebre frase de Andy Warhol. Até jornalistas, que deveriam ser tudo menos celebridades, a menos que fossem um Bob Woodward ou um Carl Bernstein terminaram, de uma hora para outra, reconhecidos nas ruas e dando palestras com polpudos cachês, nada mais antijornalístico, nada mais antiético. Até mesmo artistas decadentes se sentiram aptos a aparecerem tecendo comentários sobre política e economia, como se fossem 'experts' nos temas. Sem contar astrólogo, que se pensa filósofo, e que ganhou uma miríade de seguidores por externar seu lúgubre ponto de vista ou um economista que não deu certo na academia e nem no mercado, mas passou, através de suas ideias pedestres e preconceituosas a ter espaço nas páginas de um dos principais periódicos tupiniquim.

Este artigo, portanto, tem como objetivo analisar os principais aspectos dessa marola intelectual que atinge o Brasil, mas que nos dois últimos anos vem se transformando num tsunami e provocando grandes estragos na sociedade brasileira. Quais são seus principais argumentos e de onde parte sua inspiração e, finalmente, apontar o que está por trás de todo esse contorcionismo intelectual.

\section{Burke e o princípio do Conservadorismo moderno}

“Será possível ser um conservador em política e um radical em todo o resto?”, pergunta o filósofo conservador inglês Michael Oakeshott, no artigo “On Being Conservative”, publicado em 1956. Este questionamento e sua resposta buscavam apresentar o Conservadorismo, as confusões e as acusações que sofriam de seus críticos. Esta indagação voltou à tona entre conservadores daqui, apresentando os princípios do conservadorismo ao grande público brasileiro e ao final concluírem

REVISTA LUMEN ISSN: 2447-8717 No $1 \quad$ SÃO PAULO JANEIRO/2016 - página 61


que é possível serem conservadores em política e radical em todo o resto. O mais interessante é que ao lê-los só fica evidente a primeira parte do questionamento, pois quanto à segunda, não existe nada de concreto - algo tão prezado por eles - em sua linha argumentativa, aliás, após a leitura, fica claro que de radical só existe a palavra na frase em questão. Assim, procuraremos demonstrar através de seus escritos e do silencio face às propostas e medidas claramente reacionárias, as quais eles não apenas recusam como enfaticamente afirmam ser contrários, que estão varrendo o Brasil nos últimos meses ${ }^{17}$.

Um dos personagens mais influentes entre os conservadores é o filósofo e político irlandês Edmund Burke (1729-1797), fervoroso crítico da Revolução Francesa (1789), que tem seu marco no panfleto Reflexões sobre a revolução em França (1790), mas que irá exaltar as tradições cavalheirescas e o espírito feudal da vassalagem; a educação "gótica e monástica"; a propriedade rural herdada dos antepassados. Apesar de destilar toda sua crítica contra o novo momento, que irá denominar de "era dos sofistas, economistas e calculadores" ele não pode ser enquadrado como um intelectual antiburguês, pois seu trabalho tem uma dimensão liberal, daí a aproximação de seus futuros seguidores com o liberalismo econômico. Ou seja, ele era conservador em política e liberal em economia. A ironia é que seu partido Whig era o que reunia as tendências mais liberais na Inglaterra e que acabou originando o atual Partido Liberal Democrata e o Partido Trabalhista. O partido opositor era o conservador Tory, que reunia a aristocracia britânica, e que hoje é o Partido Conservador. Disso resulta, o contorcionismo dos atuais conservadores em justificar ora a opção dos Whigs em afastarem do trono Jaime II - que havia se convertido ao catolicismo - contra os tories - que o apoiavam -, e a defesa das opções pouco ortodoxas de Margaret Thatcher, quando foi primeira ministra pelo Partido Conservador entre 1979 e 1990.

Apesar de o terem como uma de suas referências, os conservadores brasileiros, a exemplo do que ocorrem com os conservadores de outras partes, não costumam apontar que sua raiz remonta ao Romantismo da segunda metade do século XVIII, que era o antípoda da filosofia das Luzes e do capitalismo, que irá aparecer com força no século XIX. A reverência aos valores medievais e a nostalgia de um passado que não voltará, mas que é aceita por Burke, é exaltada pelos atuais defensores desta escola. Entretanto, não convém lembrar que ela sai da mesma cepa de

${ }^{17}$ Os Conservadores não se consideram reacionários, que para eles seriam os intelectuais que são contrários ao capitalismo e procuram um retorno às sociedades pré-capitalistas. Seriam utópicos passadistas; enquanto os revolucionários seriam os utópicos futuristas. Já os Conservadores se definem como os que aceitam as mudanças que ocorrem na sociedade, desde que elas transcorram de forma lenta e que não destruam valores adquiridos pela sociedade e que nos foram passados de gerações para gerações. Segundo eles, devemos levar em conta os mortos, que nos deixaram um legado, e o que vierem a nascer.

REVISTA LUMEN ISSN: 2447-8717 No 1 SÃO PAULO JANEIRO/2016 - página 62


homens que defendiam o retorno irrestrito aos valores passadistas, denominados por eles como reacionários, e de outros que contrários ao novo mundo que ia se formando olhavam o passado com a perspectiva do futuro, chamados de utópicos. Os conservadores, dessa forma, criticam os reacionários e os utópicos. Entretanto, ao criticarem estes últimos o fazem de uma forma pouco ortodoxa e, ouso escrever, canalha, pois colocam todos os críticos da sociedade capitalista que se forma numa única caixa, a que lhes convém: a do jacobinismo, pós Revolução Francesa no século XVIII, e o regime implantado na Rússia de 1917, que era algo muito mais próximo de um capitalismo de estado do que algo aos moldes propostos por Marx ou pelos Românticos utópicos. As referências são evidentes: os utópicos futuristas, revolucionários, levam a sociedade ao caos e às execuções indiscriminadas. Nada mais falso, nada mais canalha.

O político e revolucionário inglês Thomas Paine (1737-1809), um dos Pais Fundadores dos Estados Unidos da América, e que, posteriormente, acabou por influenciar na Revolução Francesa, acreditou que após as intervenções políticas de Burke favoráveis à conciliação do Império Britânico com a colônias americanas revoltosas, que lhe valeram a reputação de liberal, este pudesse mudar para o lado dos defensores britânicos da insurreição francesa. A sua postura, que é o que o tornou celebre entre os conservadores posteriores, foi na defesa da aliança entre burguesia e proprietários rurais, que desde a Revolução Gloriosa de 1688 controlava o Estado britânico. Dessa forma, ele apenas defendeu sua posição ideológica política e social. Segundo o filósofo e poeta estadunidense Peter Viereck, a Independência dos Estados Unidos teria sido uma "revolução conservadora", pois ela ocorre a partir do momento em que os colonos começaram a exigir não serem mais taxados por um Parlamento ao qual não se sentiam representados. A sua justificativa seria a de que eles não estariam se utilizando de doutrinas abstratas, como seria o caso da Revolução Francesa, mas reivindicando as "liberdades e privilégios" estabelecidas na Metrópole. $\mathrm{O}$ apelo à Constituição seria uma atitude conservadora e que marcaria a diferença com as demais revoluções (Coutinho, 2004, p. 73). Por esta ótica a Independência dos Estados Unidos seria resultado apenas dos colonos reivindicarem seus direitos a não taxação, nada mais reducionista. Paine deve ter se revirado no túmulo.

Passagem muito mais interessante sobre o conservadorismo rasgado de Burke é o lamento de que, diferentemente da Inglaterra, na França os interesses monetários e latifundiários, devido ao fato de que a maior parte das terras estavam nas mãos da Coroa e da Igreja, mais do que separados habitavam lados opostos. Assim, não havia uma união entre estas duas classes como ocorria na Inglaterra. Como bem pontuam Löwy e Sayre, as passagens de exaltação à Idade Média 
"cavalheiresca" serve para Burke justificar o momento que a Inglaterra passava. As leis, costumes, instituições e hierarquias sócias são produtos naturais e ao mesmo tempo providenciais de um crescimento orgânico, como herança ancestral transmitida ao longo dos séculos por cada geração (Löwy e Saire, 2012, p.93).

Apesar de Burke ser um pensador político formado nas hostes do Romantismo, as suas analises, diferentemente da maioria dos críticos das Luzes e do capitalismo, serviram de apoio para o liberalismo burguês antirrevolucionário e, como podemos observar, ainda serve aos interesses do segmento dominante. Dessa forma, ele serviu, e serve, aos interesses da corrente conservadora que justifica a ordem capitalista e procura defende-la contra seus críticos, quer sejam reacionários ou utópicos. O seu objetivo é legitimar a ordem natural estabelecida como sendo algo "natural" da evolução histórica.

Dessa forma, Burke está nas origens do pensamento conservador. Entretanto, com a sociedade capitalista ganhando cada vez mais forçar no decorrer dos séculos XIX, XX e XXI, os conservadores passaram a buscar um corpo teórico. Um de seus principais representantes na atualidade, o também britânico Roger Scruton, pontua que não existe um conservadorismo universal, o que significa que ele varia de sociedade para sociedade, ou seja, são necessárias adaptações ao contextos locais. Foi esta falta de um corpo ideológico que levou o economista austríaco e um dos papas do Liberalismo econômico Friedrich Hayek a explicar que não era conservador no final de The Constitutionof Liberty (1960). Segundo ele, o conservadorismo não seria capaz de levar o desenvolvimento no longo prazo. Dessa forma, os conservadores temeriam as novas ideias, pois elas seriam incompatíveis para eles por não conseguirem ter princípios que se opusessem a elas. Duas observações interessantes: a primeira é que os próprios autores da Escola Austríaca, a qual Hayek era filiado, foram relegados a segundo plano pela escola Neoclássica, exatamente por não terem um corpo matemático em suas teorias; em segundo lugar, é que ele é hoje um dos intelectuais mais incensados pelos defensores do Conservadorismo.

É verdade que muitos opositores do Conservadorismo procuram reduzi-los, fundamentados em Burke, a uma corrente voltada às coisas do passado. Isto é verdade e é ainda mais perigoso, pois acaba por tentar ridicularizá-los e deixa uma enorme avenida para que eles possam difundir suas ideias e conquistar os corações e mentes dos menos avisados. O Conservadorismo não olha apenas o passado, ele busca no passado os elementos para manter o presente e conservar o futuro. Ao defenderem que desejam viver integralmente no presente, por aceitá-lo em todas as suas imperfeições e entende-lo como a única realidade oferecida, na verdade, procuram nos convencer 
que não há nada a ser feito, que esta é a sociedade em que vivemos com todas as vantagens e desvantagens. Desta forma, devemos aceitar a hierarquia social e o sistema econômico (capitalista) em que estamos e se quisermos mudar de status social temos como único caminho o trabalho. Na sessão seguinte veremos como se articularam Conservadorismo político com Liberalismo econômico para atingirem o seu real objetivo.

\section{Conservadorismo e Liberalismo econômico}

A partir da segunda metade do século XX os Conservadores britânicos e estadunidenses se aproximaram do Liberalismo econômico de forma explicita. Isto irá culminar com a ascensão de Margareth Thatcher, como primeira ministra da Inglaterra, em 1979, e Ronald Reagan, como presidente dos EUA, em 1980. Esta onda conservadora irá varrer primeiramente os países desenvolvidos em termos econômicos e, posteriormente, os subdesenvolvidos. A crise econômica que começa em meados dos anos 1970, impulsionada pelos gastos econômicos praticados pela principal potência na Guerra do Vietnã, a consequente fragilidade do dólar e o fim de seu lastro em 1971, o primeiro choque do petróleo em 1973, e o fim do ciclo econômico que iniciou após o final da Segunda Guerra e foi denominado de 'Os 30 Anos de Ouro', levaram o mundo a um processo de estagflação - a combinação de inflação e recessão. As políticas keynesianas ${ }^{18}$ passaram a ser contestadas pelos liberais, que estavam desde a década de 1930 relegados ao ostracismo, mas que a partir de meados dos anos 1970 passaram a ter seu discurso contra as políticas do estado keynesiano e a favor de um liberalismo econômico extremado, cada vez mais ressonante.

A ascensão dos partidos com ideologia conservadora veio dessa crise e, principalmente, da aliança com os liberais econômicos. Conservadores como o parlamentar Keith Joseph (1918-1994) foram fundamentais nesta aproximação. Thatcher foi altamente influenciada por suas idéias, tais como: políticas públicas baseadas no livre mercado, no estado mínimo, privatizações e reformas com cortes sociais. Tudo isto é justificado pelos seus adeptos como medidas que salvaram a Inglaterra do caos político e social. Todavia, alguns conservadores não enxergaram esta guinada do Partido Conservador de forma positiva. Um de seus principais críticos foi Scruton, que via esta mudança como uma subordinação do partido à modernidade e ao livre mercado, o que colocaria

${ }^{18}$ Política econômica inspirada no economista inglês John Maynard Keynes (1883-1846). Como Smith e Marx deu origem a um dos três paradigmas da ciência econômica: o keynesianismo. Apesar de ter sido formado nas hostes da economia clássica ao verificar os problemas que o mundo enfrentava após a quebra da Bolsa de Valores de Nova York passou a se opor à ortodoxia liberal. Mostrou a fragilidade e os limites dos neoclássicos, principalmente em relação ao subemprego, contra a teoria quantitativa da moeda. Após a Segunda Guerra tornou-se a referência fundamental em termos de análise e sobretudo, de definição de políticas econômicas. 
em risco os princípios e valores que davam sua linha mestra. A sua proposta era um retorno à ordem, autoridade e liberdade, como havia sido até a primeira parte do século XX. Como Burke, Scruton não é um opositor ao capitalismo ou da economia de mercado, mas, em sua concepção, essas categorias não deveriam reduzir a política e os indivíduos à subordinaçãoda esfera econômica. Talvez o puritanismo de Scruton não o levou a perceber que a aproximação das lideranças do Partido Conservador com os liberais econômicos era algo que está no DNA dos conservadores, que no século XVIII defendiam a manutenção de um estado tradicional do governo e da sociedade e visavam a restauração da sociedade vigente pré-Revolução Francesa. No frigir dos ovos, quando desejam mostrar a 'Revolução Gloriosa' e a 'Independência dos Estados Unidos' como sendo movimentos conservadores estão intimamente defendendo sociedades que estão na via do desenvolvimento capitalista, mas o que os motivam nestas sociedades são o que elas conservam das formas antigas, anteriores à modernidade. Scruton, desta forma, parece esquecer o passado conservador que, na verdade, faz o que sempre fez, ou seja, o Liberalismo econômico é o alicerce da sociedade forjada pelo sistema capitalista e tem sua base no Conservadorismo, ou seja, um está umbilicalmente atrelado ao outro.

Antes de continuarmos comentando sobre esta aliança, que, de forma implícita, acontecia bem antes da segunda metade do século XX, vamos apresentar um histórico de como de foi se formando a argamassa que irá liga- $\operatorname{los}^{19}$. O protestantismo, que surge no século XVI com a Reforma, foi fundamental para a classe mercantil que ia se formando desde o renascimento comercial na Baixa Idade Média. No final do século XVII, aumentava o número de comerciantes em busca de lucros cada vez maiores, isto implicava eliminar as restrições e regulamentações mercantilistas bem como do antigo paternalismo cristão que condenava o comportamento ambicioso e a vontade de acumular riqueza. Era necessário, dessa forma, criar uma nova teoria humana que justificasse o comportamento baseado na iniciativa individual. Assim, muitos pensadores passaram a afirmar que os motivos pessoais e egoístas eram os princípios básicos que levavam o homem a agir. O protestantismo acabou por libertar essa nova classe da condenação religiosa, como também acabou por transformar em virtudes os motivos pessoais, egoístas e

\footnotetext{
${ }^{19}$ Este parágrafo e os seguintes foram baseados nos seguintes livros: E. K. Hunt (2005). História do Pensamento Econômico. Rio de Janeiro: Campus; Jean-Claude Drouin (2008) Os Grandes Economistas. São Paulo: Martins Fontes; M. Blaug (1990). Economic Theory in Retrospect. Fourth edition. Cambridge: Cambridge University Press.Stanley L.; M. Blaug (2006). The Methodology of Economics: or how economists explain. Second edition. Cambridge: Cambridge University Press.Stanley L. Brue (2005). História do Pensamento Econômico. São Paulo: Thomson.
} 
aquisitivos que a Igreja Católica condenava. Mas não pensem que os reformadores eram modernos; na verdade eles eram muito próximos do pensamento do alto clero, ademais não esperavam que suas críticas levassem a influenciar a nova filosofia individualista. $O$ passo seguinte foi a transformação da mão de obra em mercadoria em busca de um lucro ainda maior.

O pai da economia moderna, Adam Smith (1723-1790), tentou minimizar o conflito de classes que surgia através da forma egoísta em seu proveito ou da classe ao qual pertencia através da 'mão invisível' que guiava estes atos de modo a haver mais harmonia. A ‘mão invisível' era o funcionamento sistemático das leis naturais, que solucionava automaticamente os conflitos individuais e de classes. Esta é a maior contradição da obra de Smith e que levou ao conflito das duas principais correntes econômicas nos séculos XIX e XX: uma enfatizando a harmonia social do capitalismo e a outra os seus conflitos sociais. A ideia sobre a ineficiência governamental surge de suas críticas ao Mercantilismo. Para Smith as intervenções, regulamentações, concessões de monopólios e subsídios especiais do governo alocavam mal o capital e diminuíam o bem-estar da sociedade.

Se Smith é o pai da economia moderna, David Ricardo (1772-1823) é considerado o teórico mais rigoroso da escola clássica. Como Smith, influenciou tanto o marxismo quanto as tradições neoclássicas conservadoras da teoria econômica. O momento turbulento na Europa, e particularmente na Inglaterra, com a Revolução Industrial, Revolução Francesa e Guerras Napoleônicas o influenciaram sobremaneira, principalmente, pela crescente inquietação da classe operária e a luta entre proprietários de terras e capitalistas ingleses. Defendeu o livre-cambismo e a estabilidade da moeda, a sua defesa terminou por reforçar o peso do Banco Central em questões relativas à criação de moeda fiduciária. Como parlamentar foi contrário as leis protecionistas de Reino Unido, que impediam as importações de cereais a preço baixo, provenientes do continente (cornlaws). Foi o criador da teoria das vantagens comparativas,base de sustentação da análise liberal no campo das relações econômicas internacionais.

Thomas Robert Malthus (1766-1834) é provavelmente o economista mais próximo do romantismo conservador, na definição de Lowy e Sayre (2015, p.91). Além de matemático e literato, como sacerdote tomou contato com a brutal situação das classes trabalhadoras arrastadas para o processo de industrialização. Este estado de coisas o levou num primeiro momento a defender uma redistribuição de renda entre as classes mais desfavorecidas. Entretanto, o estado de miséria vigente na Inglaterra impulsionou uma mudança de postura, pois passa a defender um pragmatismo econômico. A partir deste momento, Malthus passou a condenar a redistribuição que 
ocorria via leis dos pobres, que, segundo ele, agravaria a pobreza. Segundo este autor, as leis dos pobres nunca acabaram com a pobreza e, ao contrário, tendiam a aumentá-la. A transferência de renda sem a contrapartida da criação de riqueza levaria ao aumento dos preços e, consequentemente, à inflação de demanda. A ajuda monetária às populações menos favorecidas poderia levar ao crescimento populacional, pois não vem associada ao aumento dos meios de subsistência. Contemporâneo e amigo pessoal de Ricardo, diferiam sobre o conflito entre capitalistas e proprietários de terras. Enquanto Ricardo ficava ao lado dos interesses da classe dos capitalistas, o aristocrático Malthus se posicionava favoravelmente aos interesses da classe proprietária. Sua principal contribuição à teoria econômica foi a análise entre as relações extraordinárias e acidentais da oferta e procura: a teoria da superprodução ou das depressões. Segundo ele, as forças da oferta e da procura não são automáticas ao igualar o preço natural com o preço de mercado. Dessa forma, sempre que as forças de oferta e procura do mercado são as responsáveis pela determinação da produção de mercadorias e da alocação de recursos, isto resulta em crises econômicas ou em depressões. Sua busca era entender estas crises ou superproduções e propor soluções para minorá-las. Será em Malthus que Keynes irá buscar a inspiração da revolução que imprimirá na década de 1930.

O avanço do sistema capitalista no decorrer do século XIX levou a especialização do trabalho e ao isolamento dos produtores. Isto contribuiu para que os homens se sentissem não como uma parte integrante do sistema, mas como unidades isoladas, atomizadas, com cada um preocupado com sua própria sobrevivência contra as forças impessoais e imutáveis do mercado. Num mundo conduzido desta maneira é natural que cada um olhe para o seu semelhante como um oponente, o que estimula consciente ou inconscientemente o egoísmo. Dessa forma, no decorrer do século XIX irá surgir uma corrente de pensamento denominada de Utilitarista, cujo pressuposto é de que todos os motivos humanos eram causados pelo desejo de obter prazer e de evitar a dor ${ }^{20}$. A especialização criava, necessariamente, uma dependência individual e social, sendo o bom funcionamento do mercado, sua relativa liberdade, parte necessária do modo de produção capitalista. $\mathrm{O}$ mercado funcionando bem levava ao bem-estar da população geral e era base para a harmonia social. Esta harmonia social, originária da dependência universal do mercado, se contrapunha ao valor-trabalho que explicito nos conflitos de classes. Os teóricos do Utilitarismo ${ }^{21}$

${ }^{20} \mathrm{O}$ Utilitarismo é a base filosófica da teoria do valor-utilidade (ou perspectiva do mercado) e da moderna economia neoclássica, que irá se contrapor aos defensores do valor-trabalho (ou perspectiva da produção). Esta quebra de braço surge a partir das obras de Smith, Ricardo e Malthus.

${ }^{21}$ Os seus principais teóricos são: Jeremy Benthan, Jean-Baptiste Say e Nassau Senior. 
contribuíram para o abandono da teoria do valor-trabalho em favor de uma economia ortodoxa e conservadora. As contradições existentes nas obras em Smith e Ricardo (valor-trabalho x valor utilidade) foram afastadas e transformaram a economia ortodoxa em harmonia social. Um outro aspecto importante da especialização produtiva era a acumulação de capital (ou industrialização), isto significa que os lucros tendem a aumentar em relação aos salários para que os donos dos meios de produção, os capitalistas, possam financiar a industrialização. No período da industrialização inglesa os salários reais diminuíram em relação aos lucros e os custos sociais foram pagos pelos trabalhadores. Os Utilitaristas aceitaram esta distribuição de renda entre as classes e tentaram justificar moralmente os lucros com base nos sacrifícios feito pelos capitalistas. Por fim, o comportamento humano passou a ser explicado por estes teóricos como consequência de decisões calculadas, racionais, nas quais o indivíduo agia de modo muito parecido com um contador, ponderando todos os lucros (prazeres) a serem obtidos com determinado ato deduzido todo o custo (dor) a serem causados por este ato, e depois escolhendo racionalmente o ato que maximizasse o excesso de prazer sobre a dor.

Com os custos sociais recaindo sobre a classe operária, entre 1820 e 1850 a influência radical ou socialista da perspectiva da teoria do trabalho da Economia Política difundiu-se rapidamente ${ }^{22}$. O 'terrível outono de 1830 aterrorizou a elite dominante e os teóricos defensores do capitalismo laissez-faire. Os trabalhadores realizaram uma série de greves no decorrer daquele ano com tumultos e rebeliões com explicita demonstração de ódio e repulsa ao que a Revolução Industrial estava causando a eles e suas famílias. O que os autores radicais e socialistas irão destacar é que a industrialização e o capitalismo provocavam a destruição do modo de vida tradicional das classes trabalhadoras. A disciplina rígida nas fábricas e as deploráveis condições de vida nas cidades eram frutos de manter um emprego. O avanço tecnológico levava a um aumento do desemprego. Dessa forma, os trabalhadores se revoltaram contra: salários baixos, más condições de vida e insegurança econômica. O economista francês FredericBastiat (1801-1850) ficou horrorizado ao observar o que ocorria e procurou estabelecer, nas palavras de Hunt, a "santidade da propriedade privada, do capital, do lucro e da distribuição da riqueza existente". Tentando contrapor as teses dos principais críticos do capitalismo escreveu Economic Harmonies, publicado em 1850, em que buscava, como o próprio título afirma, que ao contrário do que os críticos do capitalismo apregoavam este sistema apresentava uma harmonia. Como forma de

\footnotetext{
${ }^{22}$ Sobre as ideias radicais e socialista ver os trabalhos de William Thompson e Thomas Hodgskin in História do
} Pensamento Economico, Hunt. 
defesa de sua tese ele comparou a Economia Política com o Socialismo, esta adotaria a 'imaginação'; enquanto a Economia Política seria 'científica', pois adotaria o método de observação. Apelou, também, para a religião, ao considerar os socialistas ateus e contra o laissezfaire, enquanto os adeptos do capitalismo seriam os crentes que gritariam laissez-passer. A partir da superioridade científica e religiosa ele desenvolve sua teoria da economia utilitarista. Na economia neoclássica utilitarista, todas as interações econômicas, políticas e sociais dos seres humanos se reduzem a atos de troca.

A formulação final da teoria do valor-utilidade ocorreu apenas duas décadas após a formulação de Bastiat em consequência da influência crescente das ideias socialistas. O pensamento marginalista teria surgido aproveitando o novo clima político e ideológico dos fins do século XIX, bem como o fracasso dos clássicos em explicar uma série de problemas puramente teóricos. Com os marginalistas inaugura-se uma nova abordagem para o valor, com a ênfase passando dos custos de produção para as condições de demanda e, portanto, sobre a troca e satisfação individual de necessidades. De acordo com o próprio Menger (1983, p. 305), o decisivo para se determinar o valor, "é a importância maior ou menor da(s) necessidades(s) para cujo atendimento temos consciência de depender de um bem" ${ }^{\text {23 }}$. Para a produção passou-se a falar não mais em classes sociais, mas em fatores de produção, com a implicação de que cada fator é remunerado por sua produtividade na margem.

Entretanto, foram de Marshall (1842-1924) e Walras (1834-1910) os maiores esforços para deslocar a economia clássica e consolidar as contribuições ainda fragmentadas do que seria a teoria neoclássica. Em seus Princípios de Economia, Marshall foi um "sintetizador..., combinando a utilidade marginal com a teoria do valor dos custos de produção" (Robbins, 1998, p. 323). Dessa síntese surgiu a análise do equilíbrio de oferta e procura num estado estacionário. Ademais, resultou dela também a descaracterização do pensamento e da teoria do valor trabalho e da distribuição de Ricardo, ocupando seu lugar:

(...) uma teoria da alocação de recursos escassos a usos específicos, sob o duplo incentivo da maximização da utilidade, para o consumidor e da maximização dos lucros, para o produtor, empregando conceitos, critérios e técnicas de análise que podiam ser aplicados, de forma análoga, a todo o sistema econômico (Deane, 1980, p.145).

\footnotetext{
${ }^{23}$ Ainda segundo Menger (1983, p. 305) "nem a quantidade de trabalho ou de outros bens necessários para a produção, ou para a reprodução de um bem, constitui o fator decisivo para se determinar o valor dos mesmos". Jevons (1983, p.28), outro expoente do marginalismo, também assinala que basta seguir "as leis naturais da variação da utilidade, enquanto dependendo da quantidade de mercadoria em nosso poder, para que cheguemos a uma teoria de troca satisfatória, das quais as leis comuns de oferta e demanda são uma consequência necessária”.
} 
Além das contribuições diretas, Marshall deixou sugestões ou indicações sutis de progresso ulterior. Como atesta Schumpeter (1970, p.107), "A literatura econômica nos trinta anos decorridos desde 1890, abunda com o desenvolvimento, as reformulações e os corolários de proposições e aspectos da técnica marshalliana". Um exemplo disso é a extensão da análise econômica a outras situações que não a de concorrência perfeita, como as de monopólio e concorrência monopolista.

Outro cuja obra foi fundamental para a edificação do pensamento neoclássico é Leon Walras. $\mathrm{Na}$ sua teoria econômica o autor concebe uma economia completa baseada em mercados e agentes individuais. O ponto central desse arranjo é a concepção segunda a qual, em condições de concorrência perfeita, com métodos de produção conhecidos e com agentes racionais manifestando suas preferências através dos sinais dos preços (escassez), é possível determinar o equilíbrio simultâneo de preços e quantidades transacionadas em todos os mercados (Robinson e Eatwell, 1978). Embora as ideias de Marshall tenham sido o principal veículo do ensino universitário da economia neoclássica até a grande depressão, os conceitos herdados de Walras foram os principais responsáveis pelo renascimento desta escola no Pós-Segunda Guerra. Isto aconteceu na medida em que houve esforços no sentido de enquadrar as contribuições de Keynes e dos neoclássicos partindo de um modelo de equilíbrio geral. Mas como resumir as contribuições à "primeira síntese neoclássica" em uma única definição? Seguindo Robinson e Eatwell (1978), a economia neoclássica pode ser definida como o estudo das trocas de bens e serviços sob a diferença de preços relativos, formados com base nas preferências subjetivas de produtores e consumidores.

Pode-se dizer que clássicos e marginalistas são classificados pela tentativa de determinação do valor na perspectiva micro. Enquanto os primeiros enfatizam o valor trabalho e os custos de produção, os marginalistas sustentam a demanda como força principal na sua determinação, inclusive dos bens de capital. Os neoclássicos, como ilustrado pelas famosas tesouras marshallianas ${ }^{24}$, atingem maior nível de generalidade na explicação da determinação do valor por levarem em consideração a interação entre a demanda e a oferta.

As primeiras décadas do século XX foram marcadas pela constituição de grandes empresas e concentração industrial, corrida imperialista entre as potências capitalistas e foi marcado por

\footnotetext{
${ }^{24}$ Conforme passagem exaustivamente reproduzida de os Principios de Marshall (1920, p. 348): "Devemos discutir sensatamente se é a lamina superior ou a inferior de uma tesoura que corta um pedaço de papel, da mesma forma que discutimos se o valor é determinado pela utilidade ou pelo custo da produção. É verdade que, quando um lado da tesoura está parado e o corte é feito movendo o outro, podemos afirmar com cautela que o corte é feito pelo segundo. Mas a afirmação não é estritamente correta e só deve servir de justificativa enquanto for apenas uma demonstração popular, e não estritamente cientifica, do que acontece".
} 
depressões cada vez mais frequentes chegando ao ápice com a quebra da Bolsa de Nova York em 1929 e a grande depressão dos anos 1930. Quem irá fazer a melhor leitura dos eventos ocorridos e porque os teóricos neoclássicos não conseguiam dar a resposta foi o principal economista do século passado, o inglês John Maynard Keynes. O surgimento da Macroeconomia ocorre como ruptura de Keynes em relação à Teoria Clássica, essa última identificada pela defesa da Lei de Say ${ }^{25}$ e pela flexibilidade de preços e salários. Tal interpretação culmina com a apresentação das Escolas Monetarista e Novo-Clássica, consideradas um retorno à tradição clássica, exatamente por seus praticantes preconizarem a economia laissez-faire. Hunt (2005), considera as contribuições a essa disciplina como parte da tradição neoclássica, incluindo as do próprio Keynes como se verá adiante. Divide, por conseguinte, a Macroeconomia entre duas escolas ligadas ao neoclassicismo, a dos neoclássicos liberais e a dos neoclássicos conservadores. Os que aceitam a participação do governo na economia para corrigir certas falhas são conhecidos por liberais; enquanto os defensores da economia laissez-faire são os conservadores. Beaud e Dostaler (1995), dividem as contribuições macroeconômicas de acordo com a oposição heterodoxia versus ortodoxia. As escolas ligadas a essa última tradição partem de alguns elementos legados pela economia clássica, integrando-os à perspectiva marginalista, com a adesão às noções de homo economicus, racionalidade e defesa do equilíbrio geral. Os autores advertem que a economia neoclássica pode coexistir com várias ideologias e orientações políticas. No entanto, desde o final da década de 1950, a renovação e a generalização da abordagem neoclássica têm andado de mãos dadas com o ressurgimento do liberalismo ${ }^{26}$.

Em A Teoria Geral, Keynes apresenta diversos aspectos fundamentais à compreensão das economias capitalistas. Os principais foram a análise dos investimentos como determinantes da renda e da poupança, as contribuições à teoria monetária, ligando o lado monetário da economia com o lado real, a ideia de que a renda cresce proporcionalmente mais que o consumo, gerando crises de demanda e instabilidade econômica. Os precursores das ideias de Keynes foram Sismondi, Malthus e Hobson, todos ressaltando as deficiências da Demanda Efetiva como causa das crises capitalistas. Antecedendo ainda tais autores, os fundamentos das ideias keynesianas podem ser encontrados na doutrina mercantilista. A concepção desses sobre a necessidade de se manter uma balança comercial favorável mostra como o excesso de exportações sobre as importações permite pressionar para baixo a taxa de juros, incentivando os investimentos e a manutenção do nível de

${ }^{25}$ Em economia a Lei de Say é aquela em que "toda oferta cria a sua demanda".

${ }^{26} \mathrm{Em}$ particular, de economistas ligados à Escola de Chicago.

REVISTA LUMEN ISSN: 2447-8717 № 1 SÃO PAULO JANEIRO/2016 - página 72


renda internamente. Em síntese, a preocupação fundamental de Keynes é em diferenciar os clássicos, partidários da noção de tendência ao pleno emprego, dos teóricos da instabilidade, ou defensores da Demanda Efetiva.

Os novos clássicos surgiram em meio à crise econômica da década de 1970, a partir dos trabalhos de Robert Lucas como uma reação contra a ainda dominante corrente keynesiana ${ }^{27}$. Outros expoentes dessa Escola são Thomas J. Sargent, Robert Barro e Edward Prescott. O ponto de partida foram algumas sugestões monetaristas, apropriadas no sentido de promover uma ruptura mais fundamental com relação às ideias da "segunda síntese neoclássica". Por trás das suas construções está a ideia de dotar a Macroeconomia de microfundamentos. Os resultados agregados passariam a ocorrer em função da tomada de decisão individual, quando da alocação de recursos pelas empresas e unidades familiares. Alguns preceitos microeconômicos foram relaxados, como o de agentes racionais e informação perfeita. Em substituição concebe-se a ideia de que os agentes tomam decisões racionais sim, mas tendo em vista a disponibilidade de informações relevantes. Arida (2003, p.23), por exemplo, define essa corrente, tanto no plano micro quanto no macro, como aquela que busca entender os “... fenômenos econômicos considerando que estes derivam de decisões individuais de agentes racionais". E isso é exatamente o que fazem os novos clássicos, praticam uma Microeconomia e uma Macroeconomia cujos resultados dependem fundamentalmente da tomada ótima de decisões por firmas e unidades familiares, ao mesmo tempo em que defendem a noção de mercados autorregulados.

A partir deste esboço da história do pensamento econômico podemos vislumbrar o quanto os conservadores políticos e liberais econômicos são próximos. Segundo o conservador português João Pereira Coutinho justifica o governo Thatcher se apoiando em conservadores que irão lembrar que ela recordou ao Partido Conservador o que já havia sido feito na era Vitoriana (18371901), citando David Willitts:

O sucesso dessa estratégia de retirar o Estado de muitas áreas da atividade econômica já tinha sido a base da prosperidade e da confiança vitorianas. A prosperidade vitoriana não apareceu por acaso; foi o resultado de um programa explícito de desregulamentação, liberalização e baixa de imposto levado a cabo por líderes políticos ao longo de várias décadas e que remonta ao assalto intelectual que Adam Smith e Edmund Burke efetuaram sobre a sabedoria convencional [isto é mercantilista]. ${ }^{28}$

\footnotetext{
${ }^{27}$ A concepção de expectativas racionais, fundamental para os Novos Clássicos, é atribuída ao trabalho de John Mutt de 1961, para quem as expectativas dos indivíduos são racionais quando são idênticas às predições desse modelo. Antes, porém, Arrow (1953) já havia discutido em termos de formulação matemática as consequências das noções de expectativas racionais em um modelo de equilíbrio geral.
}

REVISTA LUMEN ISSN: 2447-8717 No $1 \quad$ SÃO PAULO JANEIRO/2016 - página 73


E ele continua a defesa do thatcherismo mostrando que ela mostrou como se faz a defesa da "sociedade comercial” sem haver contradições entre os termos. E aí ele fecha o círculo quando afirma que ela foi buscar sua fonte de inspiração em Edmund Burke. E prossegue mostrando que a função do conservador é em primeiro lugar conservar princípios ou instituições que considerem importantes para uma comunidade estabelecida. A defesa dos conservadores do governo Thatcher é muito próxima da defesa que faz Bastiat do capitalismo. Até mesmo as expressões são muito parecidas. Coutinho vai buscar seu apoio em Adam Smith e Samuel Huntington (1927-2008), economista estadunidense que publicou, em 1968, um influente artigo defendendo o pesado bombardeio das áreas rurais do Vietnã do Sul como forma de impelir os defensores dos vietcong para as cidades.

E ele continua na defesa da "dama de ferro", pois, segundo ele, o conservadorismo deve respeitar a natureza dos homens e ao fazer isto Thatcher anuncia que antes de se valorizar a "sociedade comercial deve-se primeiro levar em conta a superioridade ética dessa sociedade. E segundo ela:

\footnotetext{
O sucesso econômico do mundo ocidental é um produto da filosofia moral...Os resultados econômicos são melhores porque a filosofia moral é superior. É superior porque começa pelo indivíduo, pela sua singularidade e pela sua capacidade de escolha. (Margareth Thatcher, In Defenseof Freedom, apud Coutinho, 2014, p.87)
}

A citação é de um utilitarismo rasgado, explicita a característica central das sociedades modernas levando a uma uniformização monodimensional e a um achatamento do sistema de valores, e reduzindo tudo ao cálculo dos interesses individuais.

A contraposição desta defesa é clara em Scruton,que começa $O$ que é Conservadorismo apontando que Conservadorismo não tem nada a ver com as políticas de um partido, inclusive que muitas pessoas podem achar isto atraente pois sente repulsa da ideia de partido. Cita, inclusive, o apelo do Partido Conservador Inglês:

(...) àquela notável e inteligente classe da sociedade [...] que está muito menos interessada nas disputas partidárias do que na manutenção da ordem e do bom governo" (Peel, The Tamworth Manifesto, 1834 in Scruton, 2015, p.44)

Dessa aversão à política partidária surge outra, talvez ainda mais poderosa, a repulsa a reforma crônica. Está aí a explicação porque os conservadores decidem adentrar à política

\footnotetext{
${ }^{28}$ David Willetts, Modern Conservatism, apud João Pereira Coutinho in As Ideias Conservadoras Explicadas a
} Revolucionários e Reacionários, p. 85.

REVISTA LUMEN ISSN: 2447-8717 № $1 \quad$ SÃO PAULO JANEIRO/2016 - página 74


partidária: para combater estas reformas. Apenas se organizando e brigando na arena política eles conseguiriam barrá-las. Mais uma vez seu mentor é Burke, que teria, segundo o autor, mesmo sendo whig, sido o "Pai Fundador" do Partido Conservador. O mais interessante é que ele surge, por volta de 1832, com o objetivo de manter a estrutura e as instituições - até aqui tudo bem - de uma sociedade ameaçada pelo entusiasmo comercial e pela agitação social. Veja, uma sociedade ameaçada pelo entusiasmo comercial é exatamente isto que Coutinho procurou defender acima e onde Scruton critica a guinada do Partido Conservador no governo Thatcher. E Scruton vai ainda mais longe, afirmando que o Partido estaria prestes a romper com sua tradição envolvendo-se:

(...) com o competitivo mercado da reforma, defendendo a delegação de poder, o sistema do internacionalismo econômico e a 'economia de mercado' contra a qual outrora se posicionava de modo tão ativo...Acima de tudo, ele começou a ver a si mesmo como o defensor da liberdade individual contra as intromissões do Estado, preocupado em devolver ao povo o seu direito natural de escolha e em introduzir em toda a corporação o princípio curativo da democracia. Estes são costumes efêmeros, bem-intencionados e nem sempre mal orientados, mas, não são, de modo algum, a expressão inelutável da perspectiva conservadora (Scruton, 2015, p. 46).

\section{Conservadorismo no Brasil no Século XXI}

O livro de Scruton deveria ser seguido como um manual para os "Conservadores" brasileiros, pois estes apregoam exatamente o contrário do que pregam os Conservadores com pedigree. $\mathrm{O}$ que estamos presenciando no Brasil nestes últimos anos é difícil de definir. A fusão entre o liberalismo e o conservadorismo, aqui, diferentemente do que ocorre na Europa e nos Estados Unidos entre 1980 e 1990 da forma a um conservadorismo muito mais deletério, pois no caso Brasileiro, a referida fusão é a própria negação do que autores conservadores, a exemplo de Scruton, apregoam. A novidade é que elas estão sendo enxertadas com o Liberalismo político. Verifiquemos, pois, como isto se deu.

A partir da ascensão à Presidência da República de Luiz Inácio Lula da Silva, em 2003, por um partido claramente definido como de esquerda, mas que no decorrer do governo deslocou-se para a posição de centro-esquerda, a sociedade brasileira viveu um momento de grande expectativa, seja a direita e a esquerda. Qual foi a surpresa que ao assumir Lula adotasse uma política econômica ortodoxa de seu antecessor. Em nenhum momento o governo contou com a simpatia da mídia e ficou evidente com o "Mensalão" em que o partido do Presidente, o PT, e o governo foram fortemente alvejados. Contudo, a guinada na política econômica com a mudança de 
ministros na pasta da Fazenda, em 2005, com o foco agora voltado não apenas na estabilidade, mas, principalmente, no crescimento, o que implicou em mais gastos na área social, levou Lula à vitória em 2006, a contragosto de boa parte da elite econômica brasileira. Contando com o bom momento econômico externo e interno em que todas as classes sociais foram beneficiadas, principalmente os extremos da base piramidal, Lula deixa o governo com mais de $80 \%$ de aprovação e faz sua sucessora, Dilma Rousseff.

Os problemas passam a aparecer a partir de 2013. No início do ano, governo e Presidenta gozavam de uma elevada aprovação, até que surgiram as primeiras manifestações contra o aumento das tarifas de ônibus, primeiro em Porto Alegre (RS) e depois em São Paulo (SP). As passeatas, que eram por problemas locais - passagens de ônibus, que é um problema da administração municipal, e violência policial contra os manifestantes em São Paulo, que é um problema do governo do estado - ganharam uma dimensão nacional e a maior prejudicada acabou sendo a própria Presidenta. As manifestações passaram a ocorrer de forma progressiva, principalmente com referência à organização da Copa do Mundo, e os manifestantes, claramente manipulados por grupos como "Vem Pra Rua", "Revoltados Online" dentre outros, passaram a criticar os gastos e atrasos nas obras e a afirmarem que não haveria Copa. Esta onda, aliada ao desempenho econômico que começava a dar sinais de esgotamento do modelo, levaram o governo a sofrer críticas cada vez mais intensas, das quais resultaram ataques pessoais à Presidenta.

$\mathrm{O}$ descontentamento das pessoas com a economia, principalmente dos grupos que não gostavam dos governos petistas, mas que os toleravam porque estavam se beneficiando economicamente, aliado às manifestações cresceu com os apelos da mídia e das redes sociais; e o ódio até então restrito ao ambiente privado, passou a ser exposto publicamente, sem qualquer pudor. Comentários pejorativos, até mesmo de colunistas como Luis Felipe Pondé, na Folha de S.Paulo - não por acaso um dos representantes dessa nova configuração - destilam preconceitos como, misoginia, homofobia, elitismo e principalmente mostra seu ódio às classes sociais menos abastadas e que têm simpatia dentre o eleitorado conservador. Para exemplificarmos como este tipo de opinião repercute entre seus simpatizantes vejamos um trecho da coluna de 15 de novembro de 2010, sob o título "A 25 mil pés", onde Pondé afirma detestar "aeroportos e classes sócias recém-chegadas a aeroportos, com sua alegria de praças de alimentação. Viajar, hoje em dia é quase sempre como ser obrigado a frequentar um churrasco na laje". A inclusão social é um dos carros-chefe do programa do PT. Além disso, se um sujeito pode escrever algo assim no jornal de maior circulação do País, qualquer um se sente no direito de escrever e dizer qualquer bobagem. E 
qualquer crítica ou discussão sobre impor algum tipo de limite ao que se escreve e fala nos meios de comunicação é rotulado como censura. Vejamos o que Scruton comenta sobre esta questão:

(...) É óbvio que não pode haver liberdade de expressão em qualquer sociedade saudável se por liberdade entendemos o direito absoluto e desimpedido que alguém tem de dizer o que quer e de exprimir seus pontos de vista sobre qualquer coisa, a qualquer momento e lugar. É necessário saber pouco sobre direito para perceber que não há liberdade absoluta de expressão no Reino Unido. Pensadores liberais sempre reconheceram este fato, mas eles julgam que as restrições à liberdade surgiram apenas como algo negativo e em respostas aos direitos individuais. A liberdade só deveria ser atenuada diante da possibilidade de alguém vir a sofrer por causa de seu exercício. Para o conservador, a restrição deveria ser mantida até que fosse ser possível mostrar que a sociedade não seria prejudicada com sua remoção...Não existe liberdade para maltratar, para incitar o ódio, para fazer ou tornar públicas declarações traiçoeiras, difamatórias, obscenas e blasfemas. (Scruton, 2015, p. 49)

É exatamente neste ponto que vejo que o que está ocorrendo no Brasil é uma apropriação de ideologias e a fusão que há de pior em cada uma delas. Estamos criando um corpo de medidas conservadoras como, por exemplo, a redução da maioridade penal e a terceirização, que se somam a outras como as criminalizações do aborto e do usuário de drogas e a proibição do casamento entre pessoas do mesmo sexo. Aliás, estamos caminhando para algo que foi muito bem exposto no artigo Conservadores Ontem e Hoje: Um Olhar sobre os Estados Unidos dos Anos 80, e que faz parte deste livro, em que seus autores mostram como os conservadores estadunidenses passaram a paulatinamente a se organizarem para combater os movimentos sociais que começavam a ganhar força nos anos 1950 e, principalmente, 1960. O resultado ocorreu a partir dos anos 1980 em que uma série de direitos sociais passaram a ser reduzidos quando não foram definitivamente encerrados. Isto beneficiou a classe empresarial, que através dos cortes gastos sociais, como, por exemplo, o seguro desemprego terminoupor forçar os trabalhadores a aceitarem empregos com baixos salários e condições precárias. Aliado a isto houve uma progressiva redução na carga tributária da elite estadunidense, que levou anos depois os EUA passarem a enfrentar problemas com seu endividamento interno. A desregulamentação da economia gerou em 2007 a maior crise econômica desde 1929.

A defesa de um "Estado Mínimo" por parte desse novo grupo surgido no Brasil é outra inovação da direita brasileira. Mais uma vez recorremos à Scruton:

(...) Nenhuma conservador sério pode acreditar que deve haver um poder maior que o do Estado, um poder que pode (caso decida) colocar-se além do alcance da lei. Os conservadores acreditam que o Estado é necessário para a autoridade deste e procurarão 
estabelece-lo e reforça-lo diante de toda influência que lhe farão oposição. (Scruton, 2015, p. 74)

Ao abordar o tema da democracia, Scruton não deixa de mostrar a que veio o Conservadorismo ao afirmar que a legitimidade de um governo não pode advir meramente da escolha democrática. Para justificar esta tese, apóia-se em Burke, quando este em sua crítica à Revolução Francesa não aceita o voto universal como parte necessária da constituição. Scruton vai ainda mais longe e afirma que é perfeitamente possível que 'a essência constitucional' britânica permanecesse indiferente se o direito ao voto fosse restrito a pessoas com posição social, educação, riqueza ou poder, àqueles, em sua opinião, que teriam um interesse autoconsciente nos destinos da nação. Muitos da classe média brasileira se lerem este trecho terão orgasmos múltiplos. Entretanto, continua Scruton, para desespero dos liberais, o conservador Disraeli ao 'roubar-lhes' a reforma eleitoral não o teria feito por considerar o sufrágio universal conservador, mas por uma questão estratégica, pois ao agir assim ele:

(...) satisfez a ideia de que os conservadores estão tanto na parte mais baixa como no topo da escala social, e de que é na classe média, com seu desdém pela discriminação de outros, que o liberalismo encontra seu lar natural. (Scruton, 2015, p. 109)

Contudo, a maior ironia reside na leitura que os conservadores fazem do estadista. Para eles, o estadista prudente é o que reconhece a pluralidade de uma sociedade, os seus valores múltiplos e rivais em que vão surgindo ao longo de seu governo. Segundo eles, um conservador sabe que a realidade é complexa e, dessa forma, não segue cartilhas ideológicas. Segundo João Pereira Coutinho o estadista deve:

\footnotetext{
(...) distinguir as "coisas acidentais de causas permanentes",na medida em que nem todas as "irregularidades" constituem um "desvio total" no curso da ação política. Para um agente conservador, é tão importante saber reformar(e o que reformar) como saber não reformar (e o que não reformar)...O político conservador, antes de reformar, deve "ver" com seus próprios olhos, "tocar" com as suas próprias mãos. E acrescenta Burke: Eu tenho que olhar para todas as ajudas e todos os obstáculos. Eu tenho que encontrar os meios de corrigir o plano, onde esses corretivos são necessários. Eu tenho que ver as coisas, que tenho que ver os homens.” (Coutinho, 2014, p. 77)
}

Por esta definição Lula, que é tão criticado atualmente por esta nova direita, seria, se não o maior estadista brasileiro, um dos maiores, na medida em que procurou, por meio de sua política, ficar bem com todas as classes sociais e, dessa forma, agindo como um reformador e não como um 
revolucionário. Seguindo esta lógica, Lula seria o maior conservador de esquerda e o maior radical de direita.

\section{Considerações finais}

Este artigo procurou apresentar alguns dos principais aspectos da teoria Conservadora e suas relações com o liberalismo econômico e como elas foram incorporadas no Brasil. Dessa forma, procuramos responder à pergunta: o que buscam os conservadores?

Parece claro que o objetivo dos conservadores é a manutenção do status-quo. Isto pode ser observado no tipo de crítica feito pelos conservadores em relação à teoria do valor trabalho, que seria menos uma teoria política do que uma teoria da exploração política. Ora, lembremos que a teoria do valor trabalho explicitava os conflitos de classe a ponto de utilitaristas e marginalistas desenvolverem uma nova teoria, a da utilidade, que explicitava uma harmonia social, para contraporem aos socialistas. Além disso, defendem que o Estado não seja mínimo, não por questões econômicas, mas para manter o direito à propriedade.

Já os conservadores brasileiros, diferentemente dos ingleses e estadunidenses, fazem uma mescla do que, em minha opinião, existe de pior entre o Conservadorismo (defesa do statusquo, defesa da redução da maioridade penal, lei antiaborto, contra a união de pessoas do mesmo sexo), e liberalismo (contrários a regulação da mídia) e do liberalismo econômico (defesa do estado mínimo). Tudo isto aliado a uma mídia que age muito mais como um partido político, aproveitando-se de uma massa de espectadores passivos e desengajados. O resultado é a exacerbação de preconceitos contra mulheres, homossexuais e, principalmente, o preconceito de classe.

Destarte, os conservadores brasileiros não devam ser subestimados, devemos combatê$\operatorname{los} !$

\section{Referências Bibliográficas}

ARIDA, Pérsio. A história do pensamento econômico como teoria e retórica. In: A História do Pensamento Econômico como Teoria e Retórica. (Orgs.) REGO, J. GALA, P. São Paulo: Editora 34, 2003. 
BLAUG, Mark. Economic Theory in Retrospect. Fourth edition. Cambridge: Cambridge University Press, 1990.

. The Methodology of Economics: or how economists explain. Second edition. Cambridge: Cambridge University Press, 2006.

BRUE, Stanley. L. (2005). História do Pensamento Econômico. São Paulo: Thomson.

COUTINHO, João Pereira. As Ideias Conservadoras Explicadas a Revolucionários e Racionários. São Paulo: Três Estrelas, 2014.

COUTINHO, João. P; PONDÉ, Luiz.F.; ROSENFIELD, Denis. Por que virei à direita. São Paulo: Três Estrelas, 2012.

DEANE, Pyllis. A Evolução das Ideias Econômicas. Rio de Janeiro: Zahar, 1980.

FONSECA. Pedro. C. D. Clássicos, neoclássicos e neokeynesianos: uma tentativa de sistematização. Perspectiva Econômica. Ano XVII, v. 11, n. 30, pg. 35-64. São Leopoldo: UNISINOS, 1981.

HUNT, Emery. K. História do Pensamento Econômico. Rio de Janeiro: Campus, 2005.

JEVONS, William S. A Teoria da Economia Política. São Paulo: Abril Cultural.(Os Economistas), 1983.

LOWY, Michael. e SAYRE, Robert. Revolta e Melancolia. São Paulo: Boitempo, 2015.

KEYNES, John. M. A Teoria Geral do Emprego, do Juro e da Moeda. São Paulo: Abril Cultural. (Os Economistas), 1983.

MARSHALL, Alfred. Principles of Economics. Eighth edition. Londres: Macmillan, 1920.

MEEK, Ronald. Economia e Ideologia. O desenvolvimento do pensamento econômico. Rio de Janeiro: Zahar Editores, 1971.

MENGER, Karl. Princípios de Econômica Política. São Paulo: Abril Cultural.(Os Economistas), 1983.

ROBINSON, Joan. Economic Heresies: some old-fashioned questions in economic theory. London: Macmillan, 1970.

ROBINSON, Joan; EATWELL, John. Introdução à Economia. Rio de Janeiro/São Paulo: Livros Técnicos e Científicos Editora, 1978.

SAMUELSON, Paul. A. Economics. Third edition. New York: McGraw-Hill, 1955.

SCHUMPETER, Joseph. A. Teorias Econômicas: de Marx a Keynes. Rio de Janeiro: Zaha, 1970.

SCRUTON, Robert. O Que é Conservadorismo. São Paulo: É Realizações, 2015.

REVISTA LUMEN ISSN: 2447-8717 No 1 SÃO PAULO JANEIRO/2016 - página 80

